\title{
Characterization of aroma compounds in the volatile fraction of soft goat cheese during ripening
}

\author{
Jean-Luc Le Quéréa, Alice Pierre ${ }^{\mathrm{b} *}$, Alain Riaublanc ${ }^{\mathrm{c}}$, \\ Denise Demaizières ${ }^{\mathrm{a}}$
}

\author{
${ }^{a}$ Laboratoire de recherches sur les arômes, Inra, 17, rue Sully, 21000 Dijon, France \\ ${ }^{b}$ Laboratoire de recherches de technologie laitière, Inra, 65, rue de Saint-Brieuc, \\ 35042 Rennes cedex, France \\ ${ }^{c}$ Laboratoire d'étude des interactions des molécules alimentaires, Inra, rue de la Géraudière, \\ 44000 Nantes, France
}

(Received 4 October 1996; accepted 5 September 1997)

\begin{abstract}
A traditional Sainte-Maure soft cheese was analyzed from 2 days to 31 days of ripening for its gross composition, total and free fatty acid distribution and the aroma compounds in the volatile fraction of cheese, which were studied by gas chromatography coupled with mass spectrometry. Cheese ripening was characterized by a very low level of casein proteolysis, $5 \%$, which was hydrolyzed in low molecular mass peptides, and by a high lipolysis level, up to $6 \%$ of free to total fatty acids at the end of ripening. The volatile fraction of cheese was studied using gas chromatography coupled with mass spectrometry. Among the 38 compounds identified in the volatile fraction, seven were characterized by olfactometry as having a specific cheese or goat cheese aroma. They were: hexanoic, octanoic, nonanoic, decanoic 3-methylbutanoic, 4-methyloctanoic and 4-ethyloctanoic. Some acids were present at levels higher than their threshold value (TV) even in 2-day cheeses, while some others only reached their TV in the 31-day cheeses, showing that the flavor of ripened cheeses was different from that of fresh cheeses. (0) Inra/Elsevier, Paris.
\end{abstract}

goat cheese / ripening / aroma compound

Résumé - Caractérisation des composés d'arôme dans la fraction volatile de fromages de chèvre à pâte molle au cours de la maturation. Un fromage de chèvre traditionnel de type Sainte-Maure a été analysé à 5 stades de maturation compris entre 2 jours et 31 jours. La maturation était caractérisée par une très faible protéolyse de la caséine $(5 \%)$ qui était hydrolysée en peptides de faible poids moléculaire. En revanche, la lipolyse atteignait des valeurs élevées en fin d'affinage, $6 \%$ des acides gras totaux du fromage étant à l'état d'acides gras libres.

\footnotetext{
* Correspondence and reprints. E-mail: apierre@labtechno.roazhon.inra.fr
} 
La fraction volatile du fromage a été étudiée par chromatographie en phase gazeuse couplée à la spectrométrie de masse. Parmi les 38 composants identifiés, 7 ont présenté, lors de l'analyse par olfactométrie, un arôme spécifique de fromage ou de fromage de chèvre. Ce sont : hexanoïque, octanoïque, nonanoïque, décanoïque, 3-méthylbutanoïque, 4-méthyloctanoïque et 4-éthyloctanoïque. Certains étaient déjà présents dans le fromage à 2 jours à des teneurs supérieures au seuil de perception organoleptique, alors que d'autres ne l'atteignaient que dans le fromage à 31 jours, montrant que la flaveur des fromages frais et maturés est différente. (C) Inra/Elsevier, Paris.

fromage de chèvre / maturation / arôme

\section{INTRODUCTION}

The typical flavor of goat cheese has first been assigned to the free fatty acid fraction, particularly the free hexanoic, octanoic and decanoic, which result from the lipolysis occurring during the maturation of cheese [9]. More recently, components present in the volatile fraction of cheeses were studied using gas chromatography coupled with mass spectrometry. Many compounds were identified, some being present at very low levels [7]. They were tested for their specific aroma and the typical goat cheese flavor has been associated particularly with the 4-methyloctanoic and the 4-ethyloctanoic. The level of these compounds in the volatile fraction of cheese was found to be higher than their olfactive threshold value [2]. It has thus been concluded that they participate to the flavor of goat cheeses.

The aforementioned data were obtained on various goat cheeses differing by their origin and type, and therefore by their fabrication steps and ripening conditions. The aim of our work was to determine the variation in the level of these specific goat cheese aroma compounds during the ripening process of well characterized cheeses originating from the same batch.

\section{MATERIALS AND METHODS}

\subsection{Cheeses}

Goat cheeses of the Sainte-Maure type, a soft cheese with a mould ripened surface, were provided by the Sèvre et Belle Factory (Celles/Belle, France) as 2-day-old cheeses. Cheese was made from raw milk from mid lactation goats (June). It involved a 24 -h coagulation step of the milk at $17-20^{\circ} \mathrm{C}$ after addition of a mesophilic lactic starter $(20 \mathrm{~mL} / \mathrm{L}$ milk) and of a rennet solution, containing $520 \mathrm{mg}$ chymosin/L ( $6 \mathrm{~mL} / 100 \mathrm{~L}$ milk). Moulding was operated by manual pouring of the curd in cylindrical moulds $(\varnothing, 6 \mathrm{~cm}$; height, $18 \mathrm{~cm}$ ). After $24 \mathrm{~h}$ of whey drainage, cheeses were taken off from their moulds, salted with dry salt and then sprayed with Geotrichum mould spores. Ripening of the cheeses was over a 31-day period with a constant temperature $\left(13^{\circ} \mathrm{C}\right)$ and hygrometry $(90 \%)$. Samples were taken off after $2,10,18,25$, and 31 days of ripening.

\subsection{Analyses}

Total solids (TS) were obtained after drying in an oven $\left(7 \mathrm{~h} ; 105^{\circ} \mathrm{C}\right)$. Fat content of cheeses was obtained using the butyrometric method of van Gulick. The Kjeldahl procedure was used to determine nitrogen matter $(\mathrm{N} \times 6.38)$. Total nitrogen matter (TNM) was determined on whole cheese samples. The $\mathrm{pH} 4.2$ soluble fraction (SN) was obtained as follow: $20 \mathrm{~g}$ of cheese was dispersed in $200 \mathrm{~mL}$ of a $2 \%$ trisodium-citrate solution, the $\mathrm{pH}$ was adjusted 
at 4.2 , a filtration on paper was achieved and the filtrate analyzed. Non-proteic nitrogen matter (NPN) corresponded to the fraction soluble in a $12 \%$ trichloroacetic solution. From these determinations the casein fraction was calculated, $\mathrm{CN}=\mathrm{TNM}-\mathrm{SN}$. The solvent water in cheese was calculated as the difference between the total water (100-TS) and the nonsolvent water bound to casein keeping the value $1.4 \mathrm{~g}$ water/g casein [19].

Individual caseins in the cheese were separated by HPLC, using a procedure described elsewhere [15]. The cheese sample $(1 \mathrm{~g})$ was dispersed in $4 \mathrm{~mL}$ of buffer $(6 \mathrm{~mol} / \mathrm{L}$ urea; trisodium citrate $1.3 \% ; 0.1 \mathrm{~mol} / \mathrm{L}$ tris-hydroxymethylamino methane, $\mathrm{pH} 7.0 ; 10 \mathrm{mmol} / \mathrm{L}$ dithiotreitol). After standing to obtain the whole dispersion of proteins and the separation of the fat at the surface, an aliquot of the lower aqueous solution was drawn up and diluted $1 / 28$ in the hydrophilic eluent of the HPLC separation, i.e., $0.1 \%$ trifluoroacetic acid in water. The $\mathrm{pH}$ was then adjusted to $2-2.5$ with a $10 \%$ TFA solution.

\subsection{Lipids}

\subsubsection{Extraction of lipids}

To an aliquot of cheese (1-2 g) $15 \mathrm{~mL}$ of a mixture of hexane/isopropanol $(2 / 1 ; \mathrm{v} / \mathrm{v})$ and 5 $\mathrm{g}$ of $\mathrm{Na}_{2} \mathrm{SO}_{4}$ were added. After mixing by a Turrax blender and centrifugation $(1000 \mathrm{~g}, 5$ $\mathrm{min}$ ), the upper phase was collected and filtered through a disposable microporous inorganic membrane (Whatman Anodisc ${ }^{\mathrm{TM}} ; 0.22 \mu \mathrm{m}$ ) using an all glass syringe.

\subsubsection{Preparation of isopropyl esters}

\subsubsection{Total fatty acids (TFA)}

$25 \mu \mathrm{L}$ of the clear hexane solution and 100 $\mu \mathrm{g}$ of heptadecanoic acid as internal standard were transferred into teflon-lined screw capping tube and isopropylated according to Wolff and Fabien [20]. The fatty acid isopropyl esters (FAIPE) were extracted by $2 \mathrm{~mL}$ of hexane and analyzed by gas chromatography.

\subsubsection{Free fatty acids (FFA)}

$5 \mathrm{~mL}$ of the lipid extract were transferred in a $100 \mathrm{~mL}$ round bottom flask, $100 \mu \mathrm{g}$ of heptadecanoic acid were added as internal stan- dard then free fatty acids were fixed on an ion exchange resin Amberlyst 26 according to Needs et al. [14]. The resin was then collected by filtration and the fatty acids were isopropylated directly on the resin as described previously.

\subsubsection{Gas chromatography}

Quantitative analyses of FAIPE were carried out on a Hewlett-Packard 5890 gas chromatograph equipped with a flame ionisation detector heated at $250^{\circ} \mathrm{C}$ and a cool on column injector. The column used was a JW DB 225 ( $30 \mathrm{~m} \times 0.32 \mathrm{~mm} ; 0.25 \mu \mathrm{m}$ film) with hydrogen $(2 \mathrm{~mL} / \mathrm{mm})$ as carrier gas. The oven chromatograph was maintained at $50^{\circ} \mathrm{C}$ for $3 \mathrm{~min}$ then programmed from 50 to $180^{\circ} \mathrm{C}$ at $10^{\circ} \mathrm{C} / \mathrm{min}$ and held at $180^{\circ} \mathrm{C}$ for $5 \mathrm{~min}$. All the FAIPE have the same response coefficient so the relative concentration of each fatty acid was expressed as surface percent of the corresponding peak in the chromatogram. Lipolysis was calculated as the ratio between free fatty acid and total fatty acid concentrations in the lipid extract determined using the $\mathrm{C} 17$ internal standard: FFA $\times 100 /$ TFA.

\subsection{Aroma compounds}

The volatile fraction of cheeses was extracted by vacuum distillation from a $600 \mathrm{~g}$ sample of cheese and compounds in the acidic and neutral extracts were separated and identified by the gas chromatography-mass spectrometry method previously described and used $[11,16]$.

\section{RESULTS AND DISCUSSION}

\subsection{Gross composition}

The cheeses were analyzed weekly over a 31-day period. A steady increase of the total solids was observed, from 32.7 to $53.6 \mathrm{~g} \mathrm{p} 100 \mathrm{~g}$ cheese (figure 1a), which involved a proportional increase in TNM and fat. The $\mathrm{pH}$ was $\sim 4.3$ in fresh cheese (figure $1 b$ ), as well in the center as on the surface of the cheese. During the ripening period, $\mathrm{pH}$ remained low in the center of cheese, but a large $\mathrm{pH}$ increase was obser- 
ved near the surface, characteristic of a ripening process monitored by a mould surface flora. This gave rise to a $\mathrm{pH}$ gradient from the center to the surface (figure $1 b)$.

During the ripening period, casein level in cheese (CN/TNM,\%) only decreased by $5 \%$ (from $92 \%$ in 2-day cheese to $87 \%$ in 31-day cheeses), with none of the indi-
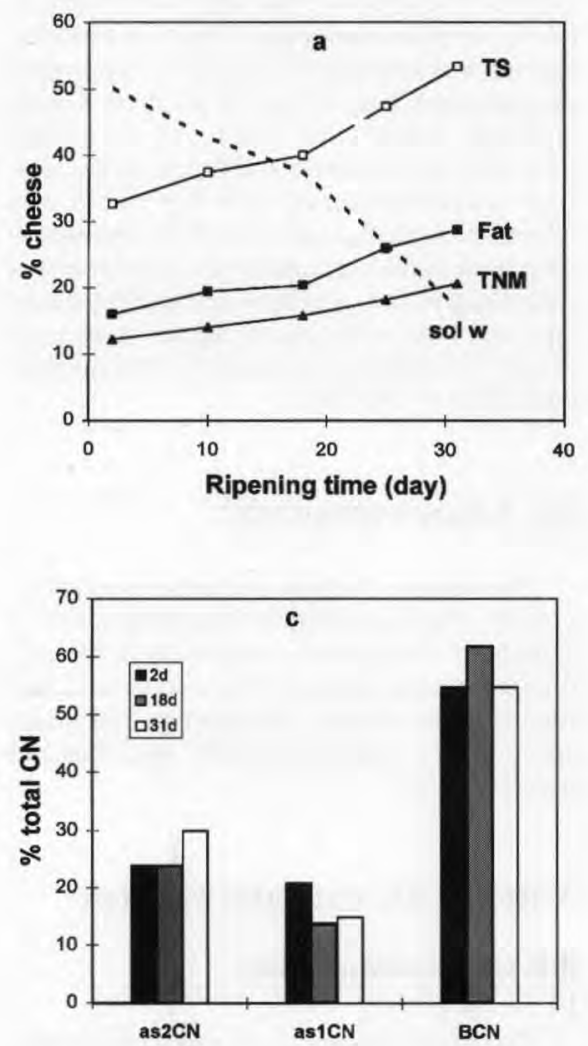

vidual caseins, $\alpha_{\mathrm{s} 2} \mathrm{CN}, \alpha_{\mathrm{s} 1} \mathrm{CN}, \beta \mathrm{CN}$ preferentially hydrolyzed (figure $1 c$ ).

Casein hydrolysis gave rise to small peptides which increased the NPN fraction from $~ 5 \%$ to $8.5 \%$ of TNM (figure $1 d$ ). This type of breakdown corresponded to the Geotrichum protease activity [6]. It is more generally a characteristic of mould proteases.
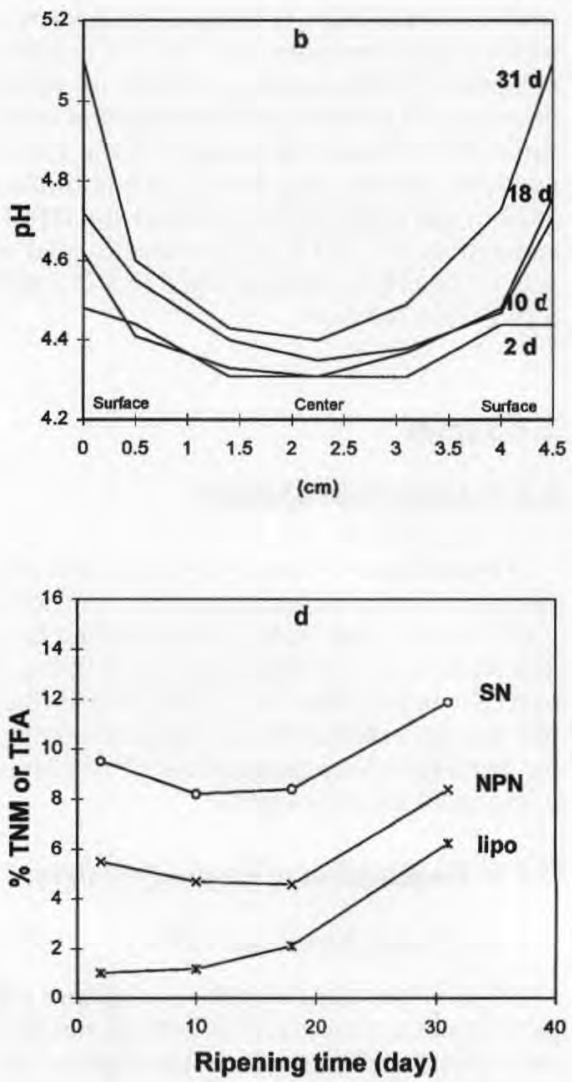

Figure 1. Variation of cheese composition during ripening. a. Total solids (TS), TNM, fat and solvent water (sol w). b. pH, in the center and at the surface of cheeses at days $2,10,18$ and 31. c. Relative amount of individual caseins in total casein of cheeses at days 2,18 and 31. d. Soluble nitrogen matter (SN), non-proteic matter (NPN) and lipolysis level (lipo).

Figure 1. Variation de la composition du fromage au cours de la maturation. a. Extrait sec (TS), matière azotée totale (TNM), matière grasse (fat) et eau solvante (sol w). b. pH au centre et à la surface des fromages après $2,10,18$ et 31 jours de maturation. c. Proportion des caséines individuelles dans la caséine totale des fromages après 2,18 et 31 jours de maturation. d. Fraction azotée soluble (SN), matière azotée non protéique (NPN) et degré de lipolyse (lipo). 


\subsection{Fatty acids}

The overall fat breakdown in cheese was estimated by the lipolysis (figure 1d). It amounted to $1 \%$ of total fatty acids in 2-day cheese, a value in the range of that in the fresh drawn goat milk [18]. It remained low during the first 18 days of ripening and then increased more rapidly, up to $6 \%$ at day 31 . Such a level of lipolysis means a high fat breakdown which can be compared to those obtained in the Camembert, $6-10 \%$, or in the Roquefort cheeses, $8-10 \%$ [6].

The relative proportions of the individual fatty acids in the total fatty acids (TFA) were determined in all the cheese samples. No variation was observed during cheese ripening. The mean values are reported in figure 2. The composition of TFA was characteristic of a goat milk fat, with a high level of saturated $\mathrm{C} 6-\mathrm{C} 14$ fatty acids compared to cow milk fat [5]. Lipolysis, measured as the proportion of free fatty acids (FFA) in TFA, increased during ripening of the cheeses. The individual fatty acids in FFA of the 31-day cheeses (figure 2), were not in the same relative proportions as in TFA. A high increase in C18:1, and to a lower extent in C16:1 and C18:2, was observed, so that the unsaturated acids reached $35.7 \%$ in FFA, compared to $24.5 \%$ in TFA. This specific activity characterized the Geotrichum lipase [12]. Moreover, the relative proportions of fatty acids in FFA varied during the course of ripening, as shown in figure 3 for some particular fatty acids. A two-step process appeared. At the beginning of the ripening period (2-day cheeses) a specific rise of the saturated C6 to C10 FFA was observed, showing the activity in the fresh cheese of a lipase with a specificity different from the Geotrichum lipase. It might be the lipoprotein lipase (LPL) of goat milk as cheese was prepared from raw milk. The highest activity of LPL is at alkaline or neutral $\mathrm{pH}$ [3], so it could have worked in the milk and in curd before its acidification. Its possible involvement in cheese ripening has already been mentioned $[8,13]$. On the other hand, somatic

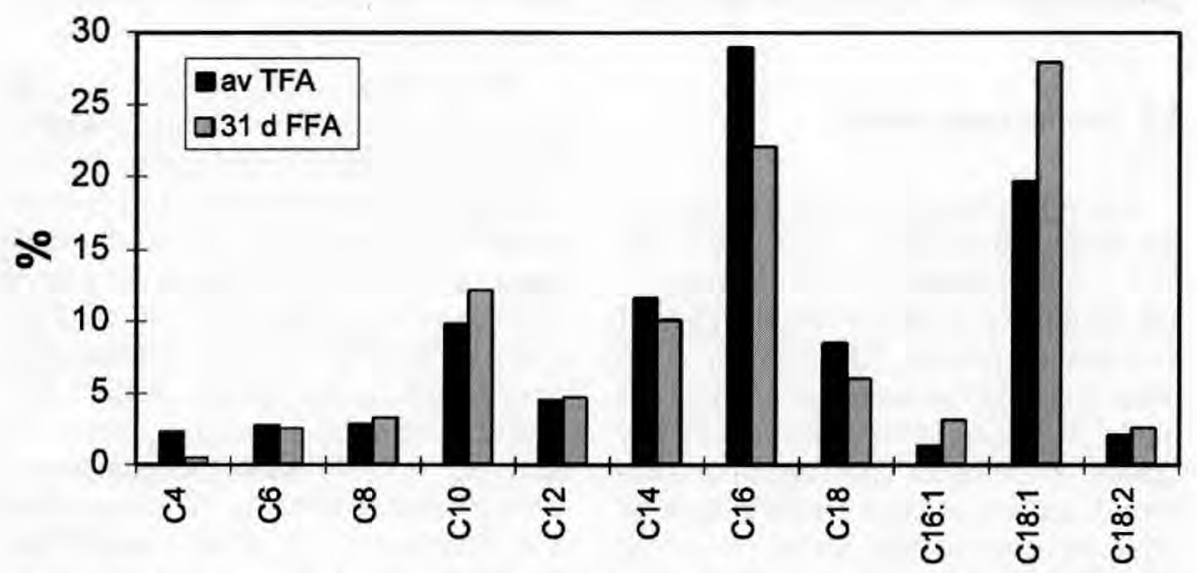

Figure 2. Composition of the TFA fraction of cheeses (average value of five determinations made on cheeses at the different ripening stages), compared to the FFA fraction of 31-day cheese.

Figure 2. Composition de la fraction acides gras totaux (TFA) des fromages (moyenne des 5 déterminations faites sur les fromages aux différents stades de maturation), comparée à la fraction acides gras libres (FFA) du fromage après 31 jours de maturation. 


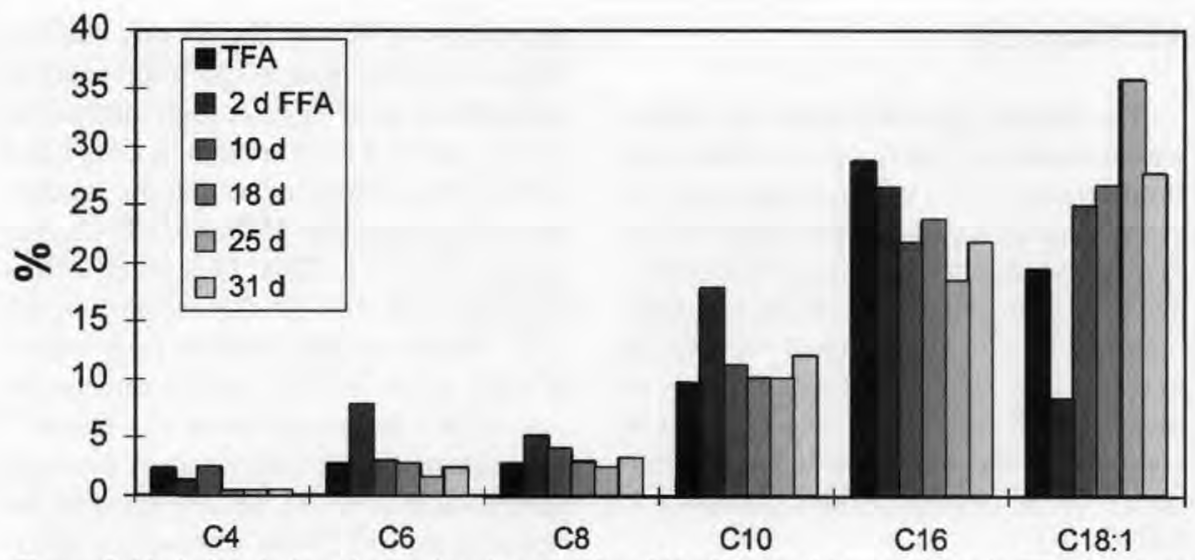

Figure 3. Variation during cheese ripening (day 2 to 31 ) of fatty acid proportions in FFA fractions, compared to those in TFA fraction (average TFA value of five determinations made on cheeses at different ripening stages).

Figure 3. Variation de la proportion des acides gras de la fraction acides gras libres (FFA) au cours de la maturation (de 2 à 31 jours) et comparaison avec la fraction acides gras totaux (TFA) (moyenne de 5 déterminations).

cells might have a lipolytic activity in milk. Their number in goat milk is high, $2 \times 10^{6} \mathrm{~mL}^{-1}[17]$ and it is possible that they could have a lipolytic activity on milk fat as in cow milk [4]. The specificities of these two goat milk lipases are not well known and it is not yet possible to specify their true role in goat milk or cheese.

\subsection{Aroma compounds}

The volatile soluble fraction of cheeses was extracted in acidic or neutral conditions and its components were identified and quantified at the different stages of the ripening process. The 38 main components are listed in table $I$ and their levels ( $\mu \mathrm{g} \mathrm{kg}^{-1}$ cheese) in the 2-day and 31-day cheeses are reported. These chemical compounds have also been characterized by olfactometry for their aroma. Some of them, in italics in table $I$, had a typical goat cheese aroma, mostly amongst the linear or branched chain free fatty acids resulting from the lipolysis, such as: hexanoic (C6), octanoic (C8), nonanoic
(C9), decanoic (C10), 4-methyloctanoic (4-meC8), 4-ethyloctanoic (4-etC8) and a non-identified compound with hardly the same retention time than $\mathrm{C10}$, thus coeluting with this compound. In addition, a non-specific 'cheese' aroma was associated with the 3-methylbutanoic (3meC4). These results agree well with previous observations [7].

The levels of aroma compounds in the cheeses at the beginning and the end of ripening have been compared to the specific aroma threshold values (TV) as determined by Brennand et al. [2]. As threshold values are very dependent on the matrix it is not sure that these TV are valid for goat cheese, which certainly confers some imprecision on our results. In the 2-day cheese, none of the aroma compounds was really above its TV while four compounds were present at levels in the range of the TV. They were, C8, C10, 4-meC8 and 4-etC8. The two last particularly have been already reported as bearing a muttony/ goaty flavor [7]. As the levels of these compounds in 2-day cheese are close to the TV, it is likely that, comparing diffe- 
rent fresh goat cheeses, very low differences in their lipolysis level would give rise to perceptible differences in the intensity of their goat flavor [8]. In the 31-day cheese, in addition to the four main aroma compounds mentioned in the fresh cheese, the $\mathrm{C} 4, \mathrm{C} 6, \mathrm{C} 7$ and 3-meC4 reached their $\mathrm{TV}$, all with values in the range $\times 5$ to $\times 10$ TV. The $\mathrm{C} 9$ which was characterized in olfactometric tests by its specific cheese aroma remained lower than its TV even at the end of ripening. On the whole, eight main aromatic compounds contributing to the goat cheese flavor have been identified in the 31-day cheese.

The differences observed in the composition of the aroma fractions in 2-day and 31-day cheeses might explain why fresh or ripened cheeses are perceived as different by organoleptic evaluation, as

Table I. Levels of compounds identified in the volatile acidic and neutral fractions of 2-day and 31-day cheeses ( $\mu \mathrm{g} \mathrm{kg}^{-1}$ cheese). The compounds having a 'cheese' or 'goat cheese' aroma are in italics.

Tableau I. Teneur des composés identifiés dans les fractions volatiles acides et neutre des fromages à 2 jours et 31 jours d'affinage ( $\mu \mathrm{g} \mathrm{kg}^{-1}$ fromage). Les composés ayant un arôme de « fromage » ou de « fromage de chèvre » sont en italique.

\begin{tabular}{|c|c|c|c|c|c|}
\hline \multicolumn{3}{|c|}{ Acidic fraction } & \multicolumn{3}{|c|}{ Neutral fraction } \\
\hline & 2-days & 31-days & & 2-days & 31-days \\
\hline Butanoic & 11 & $289(*)$ & Ethyloctanoate & 0 & 480 \\
\hline 3-me butanoic & 2 & $293^{*}$ & Ethylnonanoate & 2 & 8 \\
\hline Pentanoic & 4 & 38 & Ethyldecanoate & 4 & 901 \\
\hline Hexanoic & 2773 & $23380 *$ & Ethyl 9-decenoate & 0 & 34 \\
\hline 2-me hexanoic & 0 & 208 & Ethylundecanoate & 1 & 19 \\
\hline 4-me hexanoic & 3 & 41 & Ethyldodecanoate & 7 & 57 \\
\hline 2-et hexanoic & 21 & 41 & Ethyltetradecanoate & 16 & 38 \\
\hline Heptanoic & 103 & $509 *$ & 2-pentanol & 0 & 20 \\
\hline Octanoic & $7455(*)$ & $32958 *$ & 3-me 1-butanol & 10 & 1114 \\
\hline 4-me octanoic & $12(*)$ & $139 *$ & 2-heptanol & 1 & 253 \\
\hline Nonanoic & 95 & 390 & 1-heptanol & 7 & 13 \\
\hline 4-et octanoic & $1(*)$ & $27 *$ & 2-nonanol & 0 & 386 \\
\hline Decanoic & $3040(*)$ & $19867^{*}$ & 1-nonanol & 10 & 247 \\
\hline Undecanoic & 9 & 57 & Phenylethanol & 9 & $1007 *$ \\
\hline Benzoic & 167 & 370 & Octanol & 4 & 7 \\
\hline Dodecanoic & 134 & 618 & Nonanol & 26 & 55 \\
\hline \multirow[t]{5}{*}{ Phenylacetic } & 0 & 59 & Decanol & 14 & 16 \\
\hline & & & 2-heptanone & 10 & 156 \\
\hline & & & 3-OH-2 butanone & 78 & 97 \\
\hline & \multirow{2}{*}{\multicolumn{2}{|c|}{ Neutral fraction }} & 2-nonanone & 11 & 393 \\
\hline & & & 8-nonen-2-one & 3 & 8 \\
\hline Ethylbutanoate & 1 & 146 & 2-undecanone & 4 & 50 \\
\hline Ethylhexanoate & 2 & $258(*)$ & $\gamma$-butynolactone & 0 & 24 \\
\hline Ethylheptanoate & 12 & 7 & acetate 2 phenyl-ethyl & 11 & 83 \\
\hline
\end{tabular}

$(*), *$ : Levels hardly reaching, or higher than the threshold value.

$(*), *$ : Niveaux atteignant à peine ou supérieurs à la valeur seuil. 
well concerning the nature as the intensity of the flavor. The flavor intensity increases with the level of the compound in the cheese up to a limiting level corresponding to the saturation of the physiological receptors, which is the differential upper threshold value, different for each compound. On the other hand, the nature of the flavor is different, due to the changes in the relative proportions of the compounds and to the rise of some additional aroma compounds reaching their TV in ripened cheeses which thus participate to the flavor.
On figure 4 are presented aroma compound levels obtained from the volatile soluble fraction analysis during the course of cheese ripening for linear and branched chain fatty acids as well as for some methylcetones. Quantification of the levels was made in proportion of the total solids of cheese ( $\mu \mathrm{g} \mathrm{p} 100 \mathrm{~g}$ TS). Different types of profiles were obtained, either an increase in levels roughly proportional to the ripening time, as it was for the $\mathrm{C} 4$, $\mathrm{C} 10,4-\mathrm{meC} 8$ and 4-meC6, or a high gradient increase, from $10 \mathrm{~d}$ up to $18 \mathrm{~d}$ and no subsequent increase in older cheeses, as
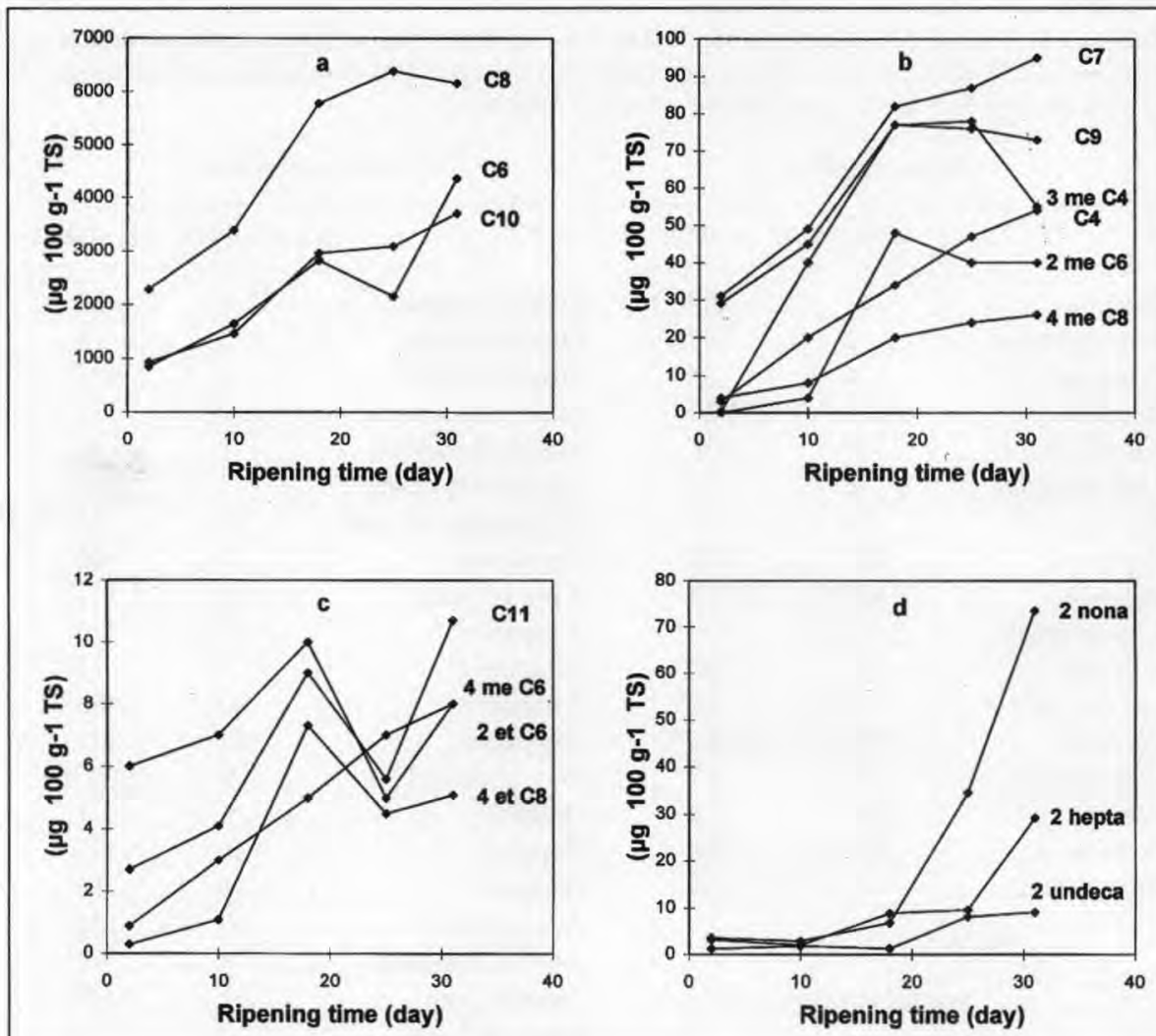

Figure 4. Aroma compound levels in cheese during ripening ( $\left.100 \mu \mathrm{g} \mathrm{g}^{-1} \mathrm{TS}\right) . \mathbf{a}, \mathbf{b}$, c. Normal or branched chain fatty acids. d. Methylcetones (2-heptanone, 2-nonanone, 2-undecanone).

Figure 4. Teneur en composés d'arôme dans les fromages au cours de la maturation ( $\mu \mathrm{g} 100 \mathrm{~g}^{-1} \mathrm{TS}$ ). a, b, c. Acides gras, normaux ou branchés. d. Méthylcétones (2-heptanone, 2-nonanone, 2-undécanone). 
it was for the $\mathrm{C} 8, \mathrm{C} 9,3-\mathrm{meC} 4,2$-meC6. Methylcetone level (figure $4 d$ ) developed differently from the other compounds with very low levels up to 18 days and then a sudden increase with a high gradient explained by the synthesis mechanism, as they were produced by a $\beta$-oxidation reaction which only takes place when the corresponding fatty acid has been released. Methylcetones are reported as the main aroma compounds in some cheeses, as blue cheeses [1], however in the goat cheeses they did not play a part in the flavor, as their level remained lower than the $\mathrm{TV}$, even at the end of ripening (table I).

As acidic aroma compounds are free fatty acids, a regular increase of their level could be expected, in relation with the lipolytic activity in cheese which was shown as increasing during ripening (figure 1d). The proportion of the individual volatile FFA extracted in the volatile aroma soluble fraction (figure 5) was low, in the range $1-5 \%$, compared to the individual total free fatty acid, released by lipolysis and estimated by gas chromatography. For some of the compounds, i.e., C6, the extracted amount was roughly proportional to the total $\mathrm{C} 6$. For $\mathrm{C} 10$, the extracted amounts seemed to increase only up to a limiting value beyond which their amount in the volatile soluble fraction became independent of their total free amount in cheese. The amount of the most hydrophobic volatile FFA in the ripened cheeses is thus underestimated by the volatile soluble extract analysis.

As a matter of fact, the FFA released in cheese by lipolysis are found either in solution in fat, concerning the most hydrophobic, or partially solubilized in the aqueous part of cheese for those having a higher solubility in water meaning short chain length FFA. This last fraction was presumably the best collected using the volatile soluble extraction method, which involved some water solubility of compounds. Almost all the volatile compounds present in the aqueous part of cheese were presumably obtained during extraction, maybe in addition to a small part only of those solubilized in fat, which however represented $95 \%$ of the volatile FFA.

The aqueous part of cheese, containing some of the most hydrophilic FFA, was modified during ripening because water evaporation at the surface of this type of goat cheese led to a reduction of the solvent water. In the 2-day cheeses, the aqueous part had approximately the same composition as whey. Starting from the 2-day cheese, the factor for volume reduction of solvent water was by 2 in 18-day cheeses and by 3 in 31-day cheeses. The concentration of all its solutes (minerals, etc.) thus increased in a reciprocal proportion. With such a change in physicochemical conditions, the solubility of FFA would presumably be modified. The activities of enzymes occurring in the aqueous phase as lipases, either soluble in the aqueous phase or only acting within, were also modified. It can be calculated that an extended ripening time could furthermore reduce the solvent water of cheese which would come to $\sim$ zero when TS reach $65 \%$. In such hard goat cheeses, really obtained with some fabrication types, the aroma compounds initially in aqueous solution might be left in a dry state and this could highly modify their vapor pressure.

Goat cheese is thus heterogeneous concerning its aroma potentialities. Its organoleptic flavor results from the volatile compounds released in mouth as well from the fat as from the aqueous part of the cheese. The extraction method we used was convenient to characterize the volatile soluble aroma fraction of cheese. It has already been demonstrated that the flavor of this extract is the best related to cheese flavor compared to other extraction techniques [10]. However, to have a more complete view of the goat cheese aroma, a head space analysis of the cheeses might 


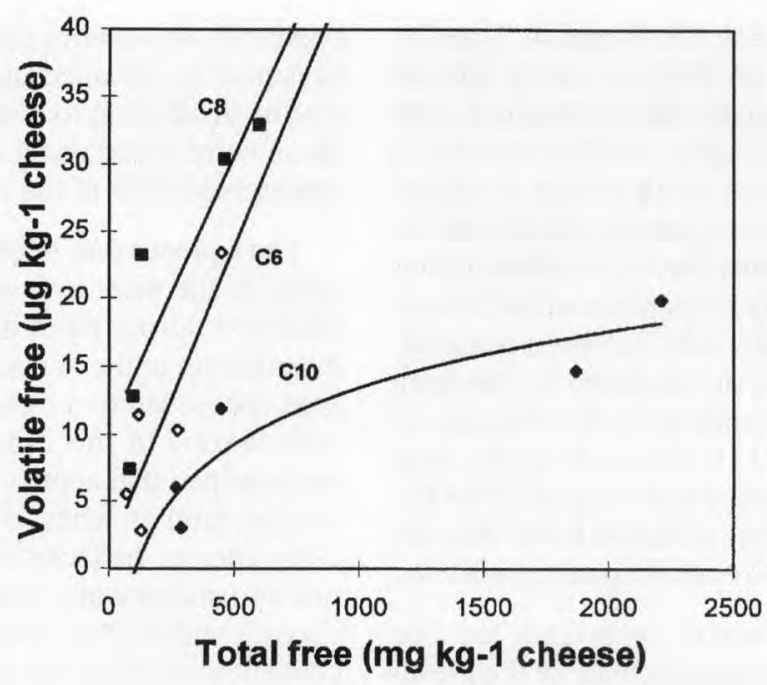

Figure 5. Amount of fatty acids $\left(\mu \mathrm{g} \mathrm{kg}^{-1}\right)$ extracted in the volatile fraction compared to the total free amount present in cheese ( $\mathrm{mg} \mathrm{kg}^{-1}$ cheese) at different ripening stages.

Figure 5. Quantité d'acides gras ( $\mu \mathrm{g} \mathrm{kg}^{-1}$ fromage) extraite dans la fraction volatile, comparée à la quantité totale présente dans le fromage $\left(\mathrm{mg} \mathrm{kg}^{-1}\right.$ fromage) à différents stades de maturation.

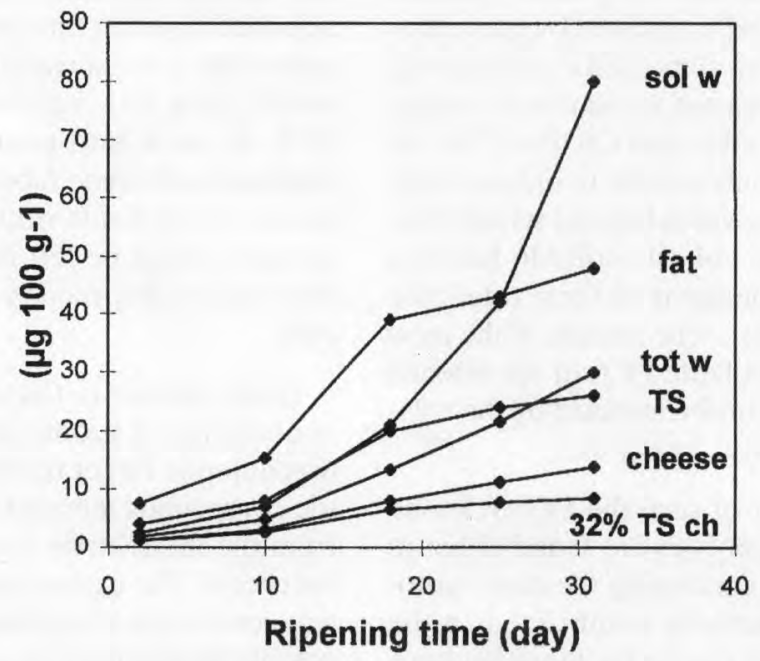

Figure 6. Variation obtained in 4-meC 8 relative concentration in cheese when calculated with reference to different cheese constituents: solvent water (sol w), total water (tot w), total solids (TS), fat, cheese, cheese at $32 \%$ TS.

Figure 6. Différence dans la teneur en 4-meC 8 selon la référence choisie pour le calcul : eau solvante (sol w), eau totale (tot w), extrait sec (TS), matière grasse (fat), fromage (cheese), fromage à $32 \%$ d'extrait sec $(32 \%$ TS ch). 
have been done in order to determine the contribution to the flavor in mouth of the remaining $95 \%$ volatile medium chain length FFA present in the cheese fat. On the other hand, as aroma compounds present in cheese might be in solution in both phases, the calculation of their levels would have to be made with reference to one or the other phase instead of to the total cheese. This would lead to very different values, as shown as an example for 4-meC 8 in figure 6 in the actual goat cheeses. Also, the threshold values are different whether in aqueous or fatty ground. A better knowledge of the role of each of the parts on cheese aroma is therefore needed.

\section{ACKNOWLEDGMENTS}

We are grateful to J.L. Maubois for facilities during the work and for his critical reading of the manuscript. We thank M. Magneron and M. Quantet from the 'Sèvre et Belle' factory for the gift of cheese samples. We thank M. Langlois for his technical assistance. The work was partially funded by a grant of 'Action Incitative Programmée' of Inra (maturation des produits alimentaires).

\section{REFERENCES}

[1] Anderson D.F., Day E.A., Quantitation evaluation and effect of certain micro-organisms on flavor components of Blue cheese, $\mathbf{J}$. Agric. Food Chem. 14 (1996) 241-245.

[2] Brennand C.P., Kim Ha J., Lindsay R.C., Aroma properties and thresholds of some branched-chain and other minor volatile fatty acids occurring in milk fat and meat liquids, J. Sens. Stud. 4 (1989) 105-120.

[3] Egelrud T., Olivecrona T., Purified bovine milk lipoprotein lipase: activity against lipid substrates in the absence of exogenous serum factors, Biochim. Biophys. Acta 306 (1973) 115-127.

[4] Gaffney P.J., Harper W.J., Lipase activity in somatic cells from separator slime, J. Dairy Sci. 48 (1965) 613-614.
[5] Glass R.L., Troolin H.A., Jenness R., Comparative biochemical studies of milk. IV Constituent fatty acids of milk fats, Comp. Biochem. Physiol. 22 (1967) 415-425.

[6] Gripon J.C., Mould-ripened cheeses, in: Fox P.F. (ed.), Cheese: Chemistry, Physics and Microbiology. 2. Major cheese groups, 2nd edn. Champman \& Hall, London, 1993, pp. 111-136.

[7] Kim Ha J., Lindsay R.C., Contributions of cow, sheep and goat milks to characterizing branched-chain fatty acid and phenolic flavours in varietal cheeses, J. Dairy Sci. 74 (1991) 3267-3274.

[8] Lamberet G., Degas C., Delacroix-Buchet A., Vassal L., Influence de caractères liés aux allèles $A$ et $F$ de la caséine $\alpha_{\mathrm{s} 1}$ caprine sur la flaveur chèvre : fabrications fromagères avec échange de protéines et de matières grasses, Lait 76 (1996) 349-361.

[9] Law B.A., Flavour development in cheeses, in: Davies F.L., Law B.A. (eds.), Advances in the microbiology and biochemistry of cheese and fermented milk, Elsevier Applied Science, London, 1984, pp. 187-208.

[10] Le Quéré J.L., Demaizières D., Negrello C., Lesschaeve I., Issanchou S., Salles C., Goat cheese flavour. Identification of the character flavour impact compounds, IDF Seminar Production and utilization of ewe and goat milk, Crete (Greece), 19-21 October, 1995.

[11] Lübke M., Le Quéré J.L., Barron D., Prefractionation of aroma extracts from fatcontaining food by high-performance sizeexclusion chromatography, J. Chromatogr. A 729 (1996) 371-379.

[12] Marks T.A., Quinn J.G., Sampugna J., Jesen R.G., Studies on the specificity of a lipase system from Geotrichum candidum, Lipids 3 (1968) 143-146.

[13] Morris H.A., Jezeski J.J., Combs W.B., Kuramoto S., Free fatty acids, tyrosine and $\mathrm{pH}$ changes during ripening of Blue cheese made from variously treated milk, J. Dairy Sci. 46 (1963) 1-6.

[14] Needs E.C., Ford G.D., Owen A.J., Tuckley B., Anderson M., A method for the quantitative determination of individual free fatty acids in milk by ion exchange resin adsorption and gas liquid chromatography, J. Dairy Res. 50 (1983) 321-329.

[15] Pierre A., Michel F., Le Graët Y., Variation in size of goat milk casein micelles related to casein genotype, Lait 75 (1995) 489-502.

[16] Pierre A., Le Quéré J.L., Riaublanc A., Le Graët Y., Demaizières D., Michel F., Composition and physico-chemical characteristics of goat milks containing the $\mathrm{A}$ or $\mathrm{O} \alpha_{\mathrm{s} 1}$ casein variants, Lait 78 (1998) 191-202. 
[17] Poutrel B., Lerondelle C., Cell content in goat milk: California mastitis test, coulter counter, and Fossomatic for predicting half infection, J. Dairy Sci. 66 (1983) 2575-2579.

[18] Rage A., Lunder T., Microbiological acid hygienic quality of Norvegian goats milk, IDF Seminar Production and utilization of ewe and goat milk, Crete (Greece), 19-21 October, 1995, pp. 128-134.
[19] Snoeren T.H., Klok H.J., van Hooydonk A.C., Damman A.J., The voluminosity of casein micelles, Milchwissenschaft 39 (1984) 461-463.

[20] Wolff R.I., Fabien R.J., Utilisation de l'isopropanol pour l'extraction de la matière grasse de produits laitiers et pour l'estérification subséquente des acides gras, Lait 69 (1989) 33-46. 